\title{
KANDUNGAN PROTEIN KASAR DAN SERAT KASAR SILASE RANSUM KOMPLIT PADA BERBAGAI BENTUK DAN LAMA PENYIMPANAN
}

\author{
Jamila Mustabi ${ }^{1}$, Rinduwati ${ }^{1}$, Mutmainna ${ }^{2}$ \\ ${ }^{1}$ Dosen Fakultas Peternakan Universitas Hasanuddin \\ ${ }^{2}$ Mahasiswa Fakultas Peternakan Universitas Hasanuddin
}

\begin{abstract}
Abstrak
Ransum dapat dinyatakan berkualitas apabila mampu memberikan seluruh kebutuhan nutrien secara tepat, baik jenis, jumlah, serta imbangan nutrien bagi ternak. Penelitian ini bertujuan untuk mengetahui pengaruh bentuk dan lama penyimpanan terhadap kandungan protein kasar dan serat kasar pada ransum komplit. Penelitian ini menggunakan Rancangan acak lengkap (RAL) dengan pola faktorial yang terdiri dari 2 faktor diantaranya faktor A (Betuk silase ransum komplit) yaitu : silase, pellet dan blok; faktor B (Lama penyimpanan) yaitu 0, 1 dan 2 bulan, setiap perlakuan diulang sebanyak 3 kali. Hasil analisis ragam menunjukkan bahwa bentuk silase ransum komplit tidak berpengaruh nyata $(\mathrm{P}>0,05)$, Namun lama penyimpanan memiliki pengaruh yang nyata $(\mathrm{P}<0,05)$, ini membuktikan bahwa tidak ada interaksi yan terjadi antara bentuk ransum komplit dengan lama penyimpanan terhadap kandungan protein kasar, akan tetapi jika dilihat pada kandungan serat kasar terdapat interaksi yang terjadi pada bentuk ransum dan lama penyimpanan. Hasil penelitian ini diperoleh kandungan protein kasar berkisar antara $10.79 \%-13,86 \%$ yang tertinggi pada penyimpanan 0 bulan dan kandungan serat kasar yaitu $14,24 \% \quad-18,93 \%$ yang tertinggi pada penyimpanan 2 bulan. Berdasarkan hasil penelitian dapat disimpulkan bahwa semakin lama penyimpanan ransum komplit maka kandungan protein kasar akan semakin menurun dan kandungan serat kasar akan semakin meningkat. Silase ransum komplit dalam semua bentuk masih mempunyai kualitas yang baik pada penyimpanan 2 bulan
\end{abstract}

Kata Kunci : Bentuk pakan, lama penyimpanan, ransum komplit. 


\section{PENDAHULUAN}

Faktor keberhasilan suatu peternakan salah satunya adalah dengan adanya ketersediaan hijauan yang cukup untuk memenuhi kebutuhan pakan khususnya pada ternak ruminansia. Hijauan memegang peranan penting pada produksi ternak ruminansia karena pakan yang dikonsumsi oleh ternak tersebut sebagian besar dalam bentuk hijauan, akan tetapi ketersediaan hijauan sangat bervariasi. Pada musim hujan ketersediaan cukup melimpah, namun sebaliknya pada musim kemarau ketersediaan hijauan masih sangat terbatas. Sehingga peternak kesulitan untuk mendapatkan hijauan dengan kualitas yang baik. Pemanfaatan limbah pertanian dan perkebunan dapat menjadi salah satu opsi untuk mengatasi hal tersebut.

Pakan komplit merupakan pakan yang mengandung nutrien yang cukup memenuhi kebutuhan ternak pada berbagai tingkat fisiologis tertentu yang diberikan sebagai satu-satunya pakan yang mampu memenuhi kebutuhan hidup pokok ternak. Semua bahan pakan, baik hijauan (pakan kasar) maupun konsentrat dicampur menjadi satu. Pembuatan pakan komplit berbahan limbah pertanian dan limbah industri pertanian merupakan salah satu alternatif pemecah suatu masalah untuk mengatasi penyediaan pakan secara kontinu

Pakan komplit dalam bentuk campuran berbagai bahan pakan yang sudah terfermentasi dapat menjadi solusi dalam pemberian pakan ruminansia dalam berbagai kondisi. Kelebihan pakan komplit adalah nilai nutrisi yang dapat diatur dengan menentukan jumlah dan jenis campuran, ternak tidak berkesempatan memilih pakan sehingga memperkecil sisa pakan yang tidak termakan, praktis, dan dapat disimpan dalam waktu yang lama. Pakan komplit dapat diproduksi dalam skala kecil, yaitu untuk peternak rumah tangga maupun dalam skala besar yaitu untuk ternak dalam skala industri. Pakan komplit dapat menjadi solusi persoalan terbuangnya waktu peternak karena tiap hari harus mencari rumput untuk menyediakan pakan ternak. Penggunaan pakan komplit diharapkan mampu meningkatkan kualitas pakan dan mengatasi keterbatasan pakan, serta meningkatkan komsumsi dan kecernaan terhadap pakan. 


\section{METODE PENELITIAN}

\section{Materi Penelitian}

Alat yang digunakan yaitu timbangan, mesin gilingan, cetakan pellet dan wafer, baskom, terpal, sekop, karung goni dan alat-alat yang digunakan untuk analisis protein kasar dan serat kasar. Bahan yang yang digunakan adalah rumput gajah (dengan kandungan protein kasar 8,69\% dan serat kasar 3,23\%), konsentrat (protein kasar 13,29\% dan 13,78\%) dan bahan-bahan yang digunakan untuk analisis protein kasar dan serat kasar.

\section{Prosedur Pembuatan Pakan Komplit}

Pembuatan pakan komplit didahului dengan mencampur rumput gajah yang telah dipotong-potong $(2-3 \mathrm{~cm})$ dan konsentrat ditimbang dengan perbandingan 50\%: $50 \%$ dan dicampur sampai homogen, kemudian dibuat silase yang difermentasi terlebih dahulu selama 15 hari. Setelah itu dicetak menggunakan cetakan pellet dan blok, dan bentuk silase. Setiap bentuk pakan dianalisis kandungan protein kasar dan serat kasar. Perlakuan terdiri dari 2 faktor yaitu bentuk dan lama penyimpanan, dan diulang sebanyak 3 kali setiap perlakuan. Rancangan percobaan yang akan digunakan dalam penelitian ini adalah Rancangan Acak Lengkap (RAL) dengan pola faktorial. Perlakuannya sabagai berikut :

$\mathrm{A}=$ Bentuk Ransum

1. Pellet

2. Blok

3. Silase

$\mathrm{B}=$ Lama Penyimpanan

0 bulan

1 bulan

2 bulan

\section{Parameter yang Diukur}

Parameter yang diukur pada pengaruh bentuk dan lama penyimpanan ransum komplit terhadap kandungan protein kasar melalui metode Kjedahl dan serat kasar (AOAC, 1991) 


\section{HASIL DAN PEMBAHASAN}

\section{Kandungan Protein Kasar Ransum Komplit pada Berbagai Bentuk dan Lama Penyimpanam}

Kandungan protein kasar pada (ransum komplit bentuk pellet, blok dan silase ransum komplit) pada lama penyimpanan (0,1 dan 2 bulan) dapat dilihat pada Gambar 1. Hasil analisis ragam menunjukkan bahwa bentuk pakan tidak berpengaruh nyata $(\mathrm{P}>0,05)$, sedangkan lama penyimpanan berpengaruh nyata $(\mathrm{P}<0,05)$, ini membuktikan bahwa tidak ada interaksi yang terjadi antara bentuk dan lama penyimpanan terhadap kandungan protein kasar. Hasil uji Duncan menunjukkan bahwa kandungan protein kasar tidak berbeda antara pakan yang disimpan selama 1 dan 2 bulan tertapi berbeda dangan penyimpanan 0 bulan.

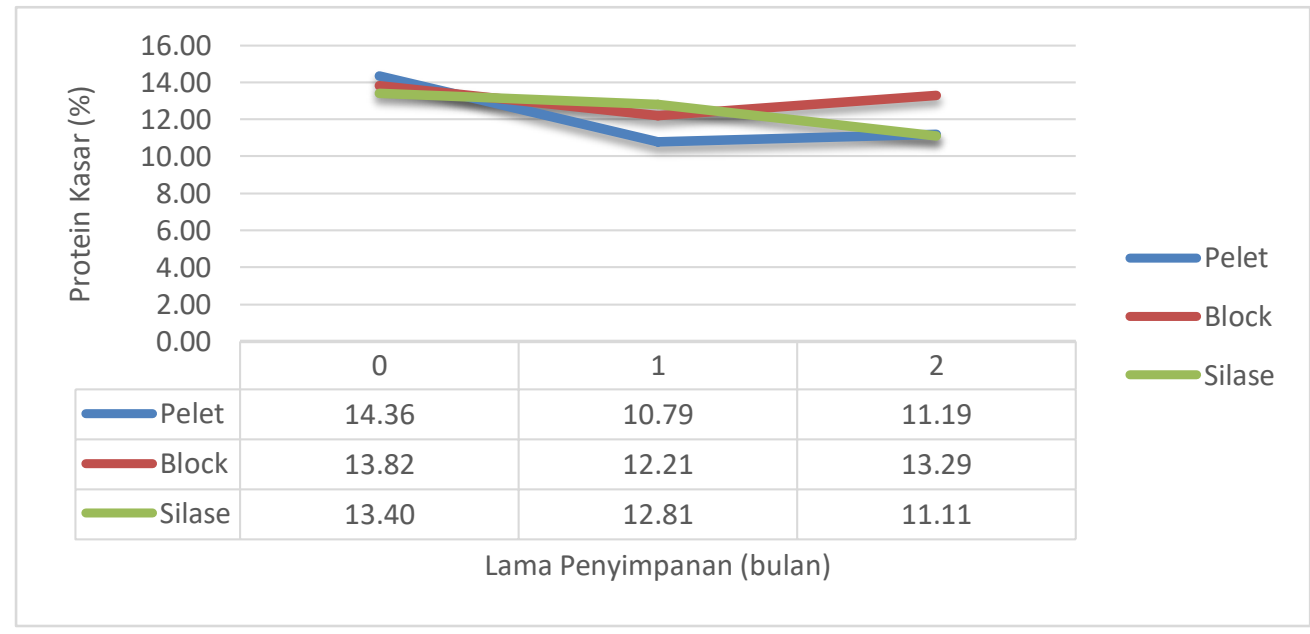

Gambar 1. Kandungan protein kasar ransum komplit bentuk pellet, block dan silase pada lama penyimpanan 0,1 dan 2 bulan.

Berdasarkan Gambar 1 terlihat bahwa pada masa penyimpanan 0 bulan kandungan protein kasar ransum komplit bentuk pellet dan blok berkisar antara $13,86 \% \pm 0,45 \%$, perbedaan ini disebabkan oleh proses pengolahan pakan sebelum dilakukan penyimpanan. Pada lama penyimpanan 1 bulan yang tertinggi adalah dalam bentuk silase akan tetapi menurun drastis pada penyimpanan 2 bulan bahkan lebih rendah jika dibandingkan dengan bentuk pellet dan blok. Hal ini dapat disebabkan karena proses fermentasi tidak terjadi lagi pada penyimpanan silase ransum komplit sehingga terdapat aktivitas mikroorganisme yang mengubah asam amino. Hal ini sesuai dengan 
pendapat Wallace dan Chesson (1995) yang berpendapat bahwa clostridia proteolitik akan menfermentasi asam amino menjadi bermacam-macam produk termasuk amonia, amina, dan asam organik yang mudah menguap.

Fermentasi juga memiliki peran penting dalam proses peningkatan protein, karena dalam proses fermentasi terdapat mikroba yang berperan dalam meningkatkan kandungan protein kasar silase. Hal ini sesuai dengan pendapat Zakaria,(2012) yang menyatakan bahwa fermentasi merupakan proses pemecah senyawa organik menjadi sederhana yang melibatkan mikroorganisme. Proses fermentasi dapat meningkatkan ketersediaan zat-zat makanan seperti protein dan energi metabolis serta mampu memecah komponen kompleks menjadi komponen sederhana. Selain itu fermentasi juga dapat meningkatkan nilai gizi bahan berkualitas rendah serta berfungsi dalam pengawetan bahan pakan dan merupakan suatu cara untuk menghilangkan zat anti nutrisi atau racun yang terkandung dalam suatu pakan. Kandungan protein kasar yang diperoleh pada penelitian ini adalah 10,79-14,36\%. Hasil ini lebih tinggi jika dibandingkan dengan penelitian yang dilakukan Fitriani dan Hasyim (2017) yang memperoleh kandungan protein kasar yaitu 9,45-10,50\% pada pakan komplit yang berbahan dasar tongkol jagung.

\section{Kandungan Serat Kasar Ransum Komplit Pada Berbagai Bentuk Dan Lama Penyimpanan}

Hasil analisis ragam pada kandungan serat kasar menunjukkan bahwa bentuk pakan dan interaksi yang terjadi tidak berpengaruh nyata $(\mathrm{P}>0,05)$, akan tetapi jika dilihat pada lama penyimpanan, interaksi antara bentuk dalam penyimpanan berpengaruh nyata $(\mathrm{P}<0,05)$. Hasil uji Duncan menunjukkan bahwa lama penyimpanan 1 bulan tidak berbeda dengan penyimpanan 2 bulan tetapi berbeda dengan penyimpanan 0 bulan. Hasil ini dapat dilihat pada Gambar 2 


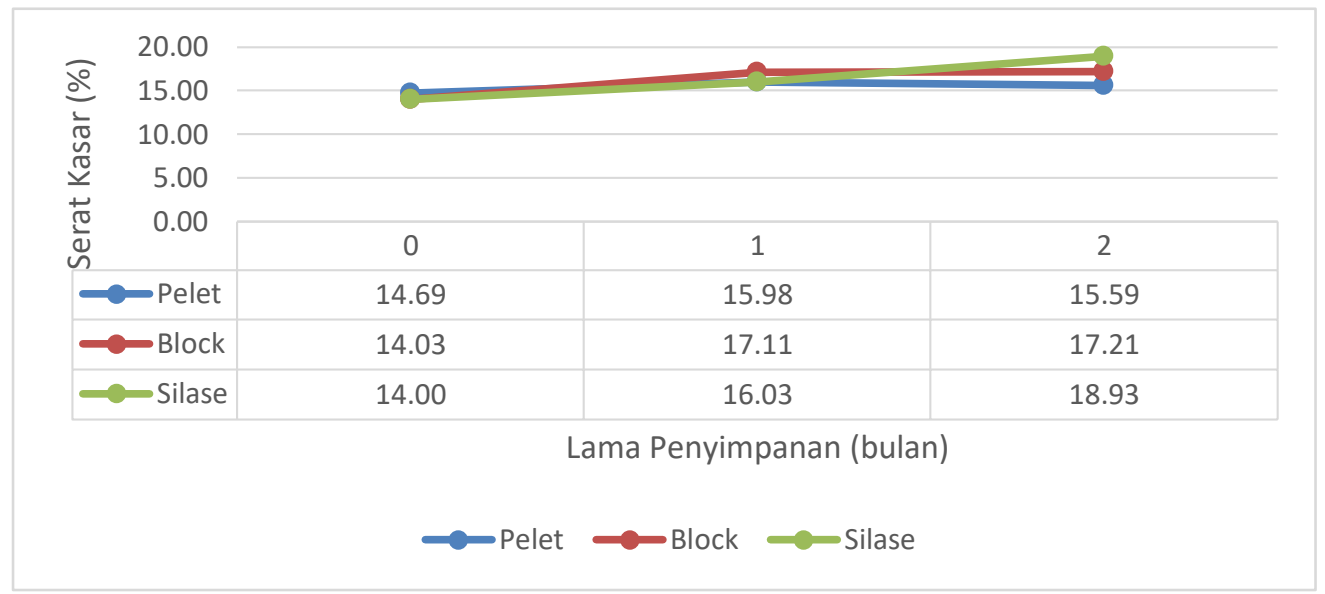

Gambar 2. Kandungan serat kasar ransum komplit bentuk pellet, block dan silase pada lama penyimpanan 0,1 dan 2 bulan.

Berdasarkan Gambar 2 terlihat bahwa pada kandungan serat kasar dengan lama penyimpanan 0 bulan antara bentuk pakan memiliki perbedaan, hal ini disebabkan akibat proses pengolahan yang terjadi. Selain itu terlihat pula bahwa semakin lama penyimpanan maka semakin tinggi pula kandungan serat kasar didalam ransum komplit pada semua bentuk. Hal ini menunjukkan bahwa akan terjadi kerusakan pasa bahan pakan jika disimpan lebih lama dalam bentuk apapun. Hal ini sesuai dangan pendapat Hall (1980) yang menyatakan bahwa penyimpanan yang terlalu lama akan berkibat buruk pada bahan makanan yang selanjutnya dapat mempengaruhi kualitas dan kuantitas ransum. Semakin lama penyimpanan maka akan dihasilkan suatu komponen cita rasa (flavor) yang lain sebagai akibat dari kegiatan biologis, contohnya pemecahan lemak yang menyebabkan ketengikan.

Menurut pendapat soesarsono (1988) yang menyatakan bahwa penyimpanan pakan dipengaruhi oleh beberapa faktor, antara lain jenis pakan, periode atau lama penyimpanan, metode penyimpanan, temperatur, kandungan air dan kelembaban udara. Kerusakan bahan pakan yang dapat terjadi dalam penyimpanan pakan yaitu kerusakan fisik dan kerusakan kimiawi. Penyimpana yang melebih waktu tertentu daln dalam kondisi yaang kurang baik dapat menyebabkan kualitas pakan mengalami penurunan (Syamsu,2002).

Penyimpanan dalam jangka waktu yang panjang dapat menyebabkan pertumbuhan Saccharomyces cerevisiae pada hijauan (hausler, 2007) dan aspergillus flavus pada beras (Winarno, 1992). Kandungan serat kasar yang diperoleh oleh penelitian ini yaitu 14,00-18,93\%, lebih rendah jika dibandingkan dengan Fitriani dan Asyari (2017) yang memperoleh kandungan serat kasar berkisar antara 20,79-21,01\% pada pakan komplit 
berbahan dasar tongkol jagung. Hai ini membuktikan bahwa pakan komplit pada penelitian ini mempunyai kualitas yang baik sampai lama penyimpanan mencapai waktu 2 bulan.

\section{KESIMPULAN}

Berdasarkan hasil penelitian yang telah dilakukan maka dapat disimpulkan bahwa semakin lama penyimpanan ransum komplit makan kandungan protein kasar akan semakin menurun namun kandungan serat kasar semakin meningkat. Silase ransum komplit dalam semua bentuk masih mempunyai kualitas yang baik pada penyimpanan 2 bulan.

\section{DAFTAR PUSTAKA}

AOAC. Association of Official Analytical Chemists. 1991. Official Methods of Analysis, of The Association of Official Analytical Chemist, Washington, D.C.

Fitriani dan Hasyim, A. 2017. Kandungan Protein Kasar dan Serat Kasar Pakan Komplit Berbasis Tongkol Jangung dengan Penambahan Azolla sebagai Pakan Ruminansia. Jurnal Galung Tropika, Vol 6 (1), Hlm 1617.

Gomez, K.A.,A.A. Gomez. 2010 Prosedur Statistik untuk Penelitian Pertanian (Terjemahkan) Endang Sjamsuddin dan J.S. Baharsjah. Edisi Kedua. UI Press. Jakarta.

Hall, C.W. 1980. Drying and Storage of Agricutural Crops. The AVI publising co., Inc westport. Connecticut.

Hausler, A. 2007. Fungi. www.microbeworld.org.(20 juli 2017)

Soesarsono. 1988. Teknologi Penyimpanan komoditas Pertanian. Penerbit: sinar Tani ,Bogor.

Syamsu. J. A. 2002. Pengaruh waktu penyimpanan dan jenis kemasan terhadap kualitas dedak padi. Buletin Nutrisi dan Makanan Ternak. Fakultas Peternakan, Universitas Hasanuddin. Makassar. Vol 1(2) : $75-83$

Wallace, J. Dan A. Chesson. 1995. Biotecnology in Animal fedds and Animal Feeding. Nutrition Division Rowett Research Institute Bucksburn. Aberdeen 
Jamila M, Rinduwati, Mutmainna/Buletin Nutrisi dan Makanan Ternak 13(1): 10-16

Winarno. 1992. Kimia Pangan dan Gizi. Penerbit PT. Gramedia Pustaka Utama, Jakarta.

Zakariah,M. A. 2012. Fermentasi Asam Laktat pada Silase. Fakultas Peternakan, Universitas Gajah Mada. Yogyakarta. 